\section{JUNE 2006}

College of Alberta Professional Foresters Annual General Meeting 22 June, Edmonton.

Contact: Doug Krystofiak at (780) 432-1177

Sustainable Forest Management Network $4^{\text {th }}$ International Conference: Sustaining Canada's Forests - Building Momentum 20-22 June, Edmonton.

Contact: Estelle.lavoie@ualberta.ca

\section{JULY 2006}

Valuing Nature: Stewardship and Conservation in Canada. 05-08 July, Corner Brook, NL. Contact: Glenda Tulk at glendatulk@gov.nl.ca

$30^{\text {th }}$ Meeting of the Canadian Tree Improvement Association: Canada's Forests - Enhancing Productivity, Protection and Conservation. 24-29 July, Charlottetown, P.E.I. Contact: kathy.tosh@gnb.ca

\section{SEPTEMBER 2006}

$10^{\text {th }}$ National Forest Congress: Sustainable Forest Management in the Boreal - A Global Challenge. 24-27 September, Gatineau-Ottawa. 1-866-441-4006 www.nfc-cfn.ca
Poplar Council of Canada Joint Meeting with Poplar Council of the United States, the US Short-Rotation Woody Crops Working Group and IUFRO Working Group on ShortRotation Crops 25-28 September Pasco, Washington State, USA. Call for papers at: www.poplar.ca/pdf/pasco2006 Info: www.poplar.ca

\section{OCTOBER 2006}

The Lake Abitibi Model Forest and the Canadian Institute of Forestry are proud to host:

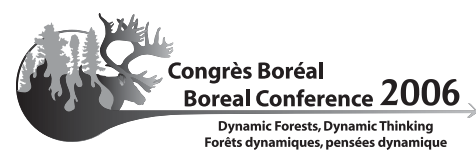

The Boreal Conference 2006

1-4 October

with optional field trips Oct. 5 \& 6

Cochrane / Moosonee /

Moose Factory, Ontario.

www.borealconference2006.ca

Leading Edge 2006 - Niagara Escarpment Commission's Conference on Sustainability, Healthy Communities and Biosphere Research. 04-06 October, Burlington, Ontario. www.escarpment.org
Sustainable Forest Management with Fast Growing Plantations.

10-13 October,

Charleston, North Carolina. www.iufro.org/science/divisions/ division-4

Seventh Canadian Urban Forestry Conference - "The Tree at the Centre of Urban Development" 11-13 October, Quebec City. Contact: Michael Rosen at mrosen@treecanada.ca

\section{Colloque Eastern CANUSA} sur les sciences forestières/Eastern CANUSA Forest Science Conference 19-21 octobre/October

Pavillon Alphonse -

Desjardins Université Laval

Québec (Québec)

www.mrnf.gouv.qc.ca/ecanusa

\section{MARCH 2007}

2nd Fire Behaviour and Fuels Conference - Fire Behaviour Fundamentals and Applications 26-30 March, San Diego. www.iawfonline.org 